\title{
Konka Board: a cement-pumice-tow sheathing board
}

Nigel Isaacs, School of Architecture, Victoria University of Wellington

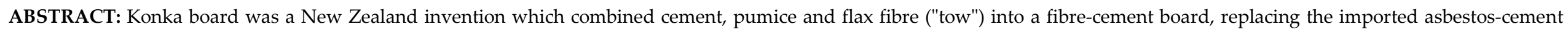

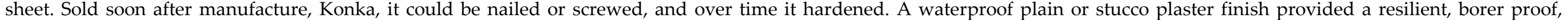

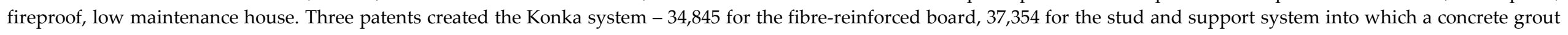

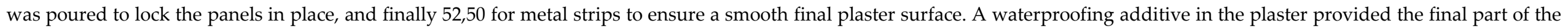
system.

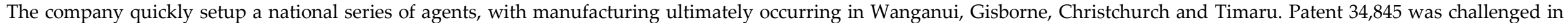

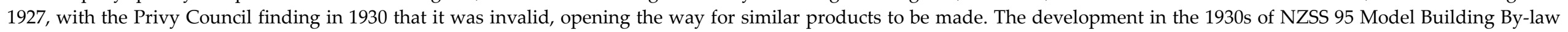

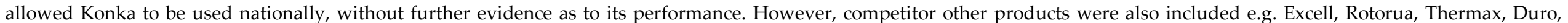
Wangan, Walasco and the asbestos based Fibrolite.

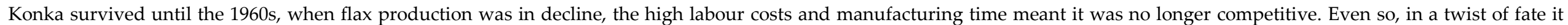

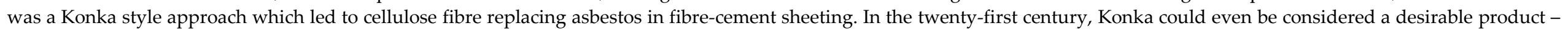
a natural fibre reinforced, composite sheet.

\section{Introduction}

Although Eternit asbestos-cement sheets (first patented 1900) and tiles for use for lining ceilings, inside and outside walls and partitions were advertised as being available in Wellington in 1907, ${ }^{1}$ by 1915 the imports of asbestos cement sheeting were significant enough to be included in import statistics, ${ }^{2}$ and in 1921 in the census reports of house wall construction. ${ }^{3}$ There were at least nine

\section{1 "'Eternit"' p 7.}

${ }^{2}$ Isaacs "Making the New Zealand House 1792-1982" pp 169-172.

${ }^{3}$ Isaacs "Making the New Zealand House 1792-1982" p 35. asbestos cement brands available by 1920 . This increasing demand for cement sheeting most likely led to the development of import substitution products, the best known of which being KONKA Board.

\section{Inventing a New Wall}

Roland Moor Maunder was an active inventor. His first patent in 1899, with William Steere Maunder (an older brother), was for an "Improvement in Clothes Horse,"4 although the following eight patents were solely in his ${ }^{4}$ Maunder \& Maunder "Improvements in Clothes
Horses" p 5. name. The two patents which eventually became "Konka" were number 34,845 issued in 1914 for "Reinforced concrete tiles ${ }^{5 "}$ and 37,354 for "Wall, Fence, etc. Construction" in 1916. ${ }^{6}$ A third patent in 1924, number 52,590, for "Building Construction" completed the suite.

Patent 34,845 set out the mixture for the manufacture of the board or tiles. The goal was for a relatively thin (and light) tile that did not crack while setting and was not liable

\footnotetext{
${ }^{5}$ Maunder "Reinforced Concrete Tiles" p 5.

${ }^{6}$ Maunder "Wall, Fence, Etc Construction" p 9.
} 
to breakage when being placed in position or during normal use. As the tile was not expected to be left uncovered, it also needed to be suitably porous to take a plaster covering. The base mixture claimed in the patent comprised of 3.5 parts of pumice to 1 part of cement 1 and 0.36 parts of flax tow, with sufficient water, although this was adjusted in practice. ${ }^{7}$ This mixture was moulded in slabs approximately $5 / 8$ in thick which "may be nailed or screwed to the building framework."8 The Konka sheets were delivered in the immature ("green") state, and fully hardened in about 12 months. ${ }^{9}$ The manufacture of Konka board was labourintensive and space intensive. Flat, paperlined frames were filled with a hand-mixed concrete-pumice slurry. Flax tow was added, and the board cured for three days, the frame removed and then the sheet hung to naturally dry. ${ }^{10}$

Patent 37,354 provided the design of a corner and central stud moulds to hold "reinforced concrete" slabs or sheets in place in

\section{${ }^{7}$ Russell v Maunder p 2.}

${ }^{8}$ Maunder "Reinforced Concrete Tiles $(34,845) "$ p 2.

9 John Jackson \& Co Ltd Cosy "Konka" Homes of New

Zealand $\mathrm{p} 6$.

${ }^{10}$ Wrigglesworth Take Me with You! p 115.

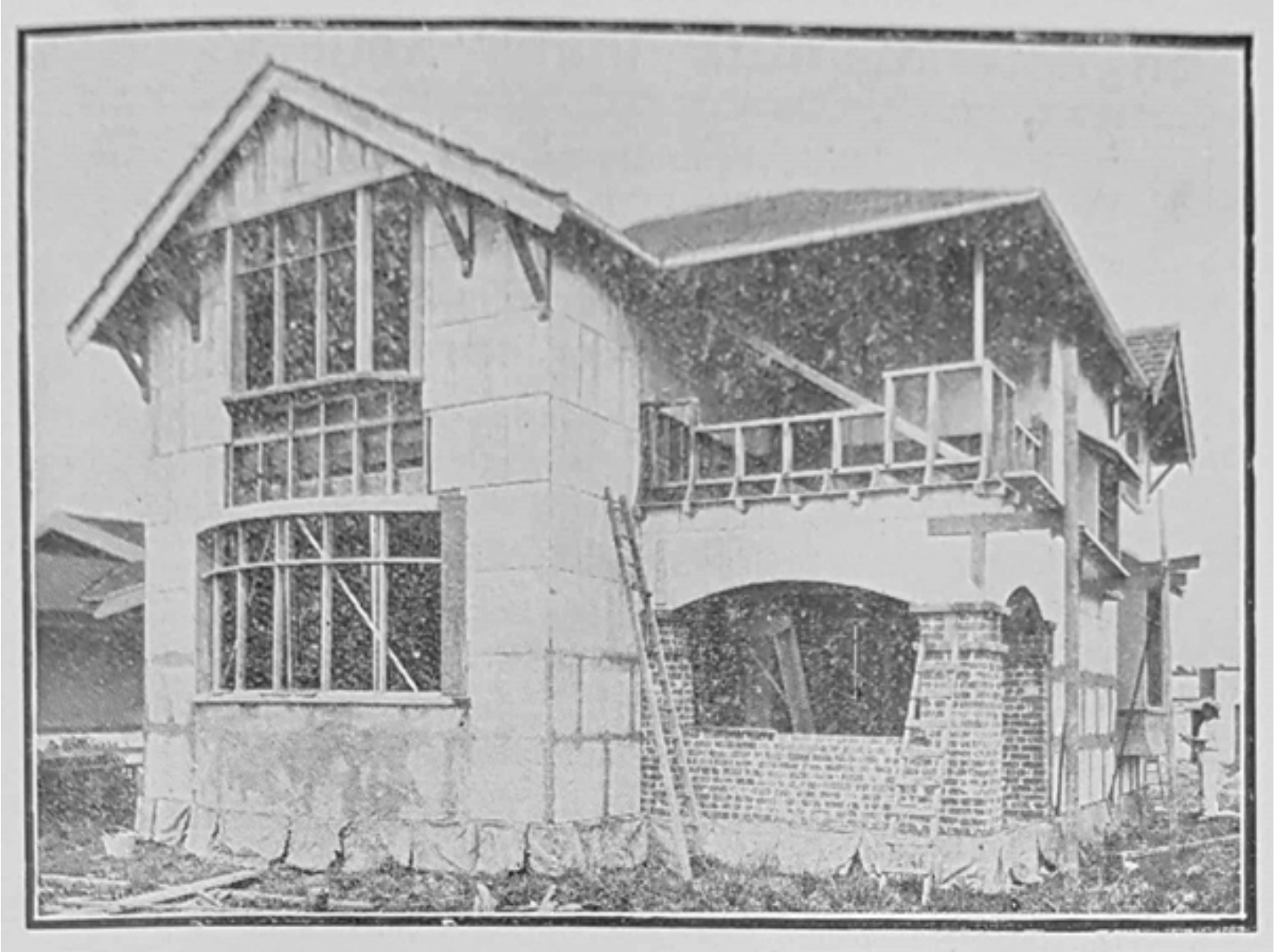

Figure 1: "KONKA" house under construction (John Jackson \& Co. Ltd Cosy 'Konka' Homes of New Zealand p 25, Model Building By-law - NZ Standard Code of Building By-Laws - Timber Buildings, Archives New Zealand, Wellington. Ref: R22354942 (AEKP 19011 ST6/24 Record 95 Part 9).

preparation for grouting. Reinforcing steel was arranged within the stud moulds and "distance pieces" (normally wood) arranged to maintain separation between the outer and internal sheets. Once the concrete had set, the outer mould plates and the "distance pieces" 
could be removed. This left a concrete framework supporting the cement sheets, which would then be externally plain or stucco plastered. ${ }^{11}$

The final patent, number 52,590, was for thin metal strips (or "scrimming"), held in place by nails or screws to cover over the gaps between sheets on the flat or at corners. These strips provided a surface for the plaster to key, or lock, in place as well limiting potential sheet movement and providing a smoother finish. By 1925 hessian dipped in cement slurry was being used to cover the joints. ${ }^{12}$

One other step was required - to limit the penetration of water through the concrete plaster to the sheet and hence indoors. The product "PUDLO" Mineral Waterproofer solved this problem when added to the finishing plaster or stucco. PUDLO is a hydrophobic and pore blocking admixture, which is still sold. ${ }^{13}$

Figure 1, taken from a Konka promotional booklet, illustrates a house under construction

${ }^{11}$ Maunder "Wall, Fence, Etc Construction $(37,354)$ " pp 25.

${ }^{12}$ NZSI "'Konka" Board" p 2.

${ }^{13}$ DB Group PLC "UK Waterproofing Solutions." awaiting the grouting and scrimming of the joints, showing the joints between the sheets, both horizontal and vertical.

Konka board was sold as comparative small sheets. In the 1923 promotional booklet the dimensions are given as $3 \mathrm{ft} \times 2 \mathrm{ft} \times 5 / 8$ in $(0.9$ $\mathrm{m} \times 0.6 \mathrm{~m} \times 0.016 \mathrm{~m}){ }^{14}$ while in 1952 published sizes were: $3 \mathrm{ft} \times 2 \mathrm{ft} 6$ in $(0.9 \mathrm{~m} \mathrm{x}$ $0.8 \mathrm{~m})$ and $3 \mathrm{ft} 4$ in $\times 2 \mathrm{ft} 6$ in $(1 \mathrm{~m} \times 0.8 \mathrm{~m})$, with a finished thickness of $1 \frac{1 / 4}{4}$ in $(0.032 \mathrm{~m})$ (after plastering). ${ }^{15}$ A 2009 article gave the size as $3 \mathrm{ft} \times 1 \mathrm{ft} 6$ in $\times 2$ in $(0.9 \mathrm{~m} \times 0.45 \mathrm{~m} \times 0.05$ $\mathrm{m}),{ }^{16}$ but this seems too thick and too short compared to the earlier documentation.

\section{Harakeke or Swamp Flax (Phormium tenax)}

Māori used harakeke for making clothes, ropes, fishing nets, baskets, mats, etc. Early European visitors recognised its value for making rope for sailing ships. By the 1860s machines had replaced the laborious manual process of stripping the flax fibre. The industry grew, and at its peak between 1901 and 1918 flax fibre made up almost 5\% of New Zealand's exports. However, due to a

${ }^{14}$ John Jackson \& Co Ltd Cosy "Konka" Homes of New Zealand $\mathrm{p} 4$.

${ }^{15}$ Cranwells Building Supplies Catalogue p 2/5, 1952.

${ }^{16}$ Aitkens Concrete Ltd "Aitkens Concrete Ltd" p 8. combination of "yellow leaf" disease, reduced international demand and finally a global depression the market fell. Government support plus - in the 1950s - the use of flax for woolpacks led to a recovery, but the removal of government protection in the 1970s and competition from synthetic fibres finally closed the industry. ${ }^{17}$

In the 1930s flax was used for matting, binder twine and lashing. It was also used in smaller quantities as a binder in plaster, in paper manufacture, mattress and upholstery stuffing, and occasionally in rope. ${ }^{18}$ Although the long flax fibres were desired, a by-product was "tow" or short fibres. These were used by upholsterers, for the manufacture of underfelting, for fibrous plaster ${ }^{19}$ and, as discussed earlier, for the manufacture of Konka board.

While the invention of Konka could be considered as a substitute for asbestos cement sheets, the use of plant fibre was more sustainable ultimately replacing asbestos. James Hardie Ltd had been manufacturing Fibrolite asbestos cement at its Penrose,

\footnotetext{
${ }^{17}$ Swarbrick "Flax and Flax Working" n.p.

${ }^{18}$ Critchfield "Phormium Tenax" p 182.

${ }^{19}$ Sparrow "The Growth and Status of the Phormium
} Tenax Industry of New Zealand" p 342. 
Auckland plant since 1938 but from September 1983 a plant fibre - treated cellulose (unbleached softwood Kraft pulp) replaced the asbestos. ${ }^{20}$

\section{In Business}

The earliest advertisements found for Konka board were in September 1914:

WANTED - All architects, builders and everyone to see the wood substitute "Konka" in Collinson and Son's window. ${ }^{21}$

Collinson and Son's were general ironmongers located in The Square, Palmerston North. ${ }^{22}$ On 4 November 1914 the "Konka Tiling Company" of "Fitzroy St, Palmerston North" had a stand in the Machinery Hall of the Manawatu A \& P Show - after the first patent for tiles (8 May 1914), but before the second for the construction technique (7 April 1916). As to the invention, the local newspaper reported:

"Konka" is the invention of two well-known local residents and is rapidly taking the place of wood for

\footnotetext{
${ }^{20}$ Carroll, A Very Good Business pp 79, 220, 230.

21 "Wanted - All architects [Advertisement]" Manawatu Standard (11 September 1914): 1.

${ }^{22}$ The Cyclopedia of New Zealand: Taranaki, Hawke's Bay and Wellington Provincial Districts VI p 682.
}

building purposes. ${ }^{23}$

Konka was being promoted as "permanent, borer proof, fireproof, saves painting maintenance" as well as "warmer in winter and cool in summer."24 By August 1915, Konka had been accepted by the ValuerGeneral for use in houses funded by State Advances. ${ }^{25}$

In 1916 Konka North Island agents were: Durward and Davidson, Manawatu; Green and Bevan, Wanganui; Ellis and Bernaid, Hamilton; Wilson's Portland Cement Co., Auckland; Cement Pipe Co., Ltd., Masterton; Ryan and Phillips, Napier; and Francis Holmes, Wellington. ${ }^{26}$

By 1922, Konka was still being made by the Konka Tiling Company of Fitzroy Street, Palmerston North but manufacture was also being undertaken by Bassett \& Co. of Whanganui, Aitkens Concrete of Gisborne and the Jarrah Timber Company of Christchurch. ${ }^{27}$

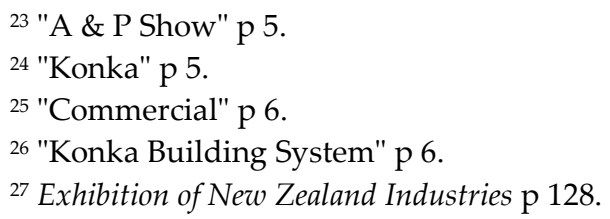

In June 1916 a number of "building experts from Wanganui" were invited to Palmerston North to view the Konka building system under manufacture and construction. They included Mr FG Beaven, of Green and Beaven (the Wanganui Konka agent), who is reported to have said "This new system will revolutionise the building industry." ${ }^{28}$ In 1918 the two Wanganui business of Green and Beaven Ltd "timber, joinery cement and Konka merchants" merged with Bassett and Co. Ltd, ${ }^{29}$ although their furnishing went to the Popular Furnishing Company. ${ }^{30}$ In 1919 Bassett and Co. Ltd. reported that "considerably over 50,000 feet of "Konka" have been used in Wanganui and district alone" and they were "the Dominion manufacturers for the patentee."31 In 1929 an article in the Wanganui Chronicle reported that Konka manufacture and distribution were now controlled in Wanganui. ${ }^{32}$

In 1929, Bassett and Co. were the

sole and exclusive licensee ... for the Provincial Districts of Wellington and Taranaki and parts of the Provincial

\footnotetext{
28 "Konka Building System" p 6.

29 "Business Notes" p 8.

30 "Public Notice" p 7.

31 "Solving the Housing Problem" p 3.

32 Wrigglesworth Take Me with You! pp 114-115.
} 
District of Hawkes Bay and entitled to establish agencies ... in the Auckland Provincial District and in the whole of the South Island. ${ }^{33}$

They made a significant impact on Wanganui housing, with advertising claiming that: "Wanganui has a Dominion reputation for its "pretty homes," 75\% of which are "Konka."34

In 1921 John Jackson and Co Ltd of Timaru purchased the Konka manufacturing rights for South Canterbury and North Otago, setting up a factory. They started active promotion of the product, including informing the Timaru Harbour Board of its suitability for the Board's housing scheme. ${ }^{35}$ Jackson's the first newspaper advertisement dates from March 1930. ${ }^{36}$ In 1931 Jackson's advertised their wide range of New Zealand made goods, including drainpipes, fire bricks, plaster board, cement, lime, fireclay, "And last, but not least Konka Wall Sheets." 37

The use of Konka board was so widespread that in 1925 that the NZ Government Railway

\footnotetext{
${ }^{33}$ New Zealand Gazette (3 October 1929) n 66, p 2602,

${ }^{34}$ John Jackson \& Co Ltd Cosy "Konka" Homes of New

Zealand $\mathrm{p} 1$.

35 "Harbour Board" p 9.

36 "Konka Defies Time Fire Rot Borer" p 14.

37 "Build Your Homes" p 16.
}

"Scales of Charges" specifically included: "Concrete Sheets (Konka Board)" which were to be carried at "Owner's risk." The pricing class (and owner's risk) was the same as for "Asbestos Roofing-slates."38

\section{Patent - Valid or Invalid?}

In 1924 the Wanganui Sash \& Door Co. announced they were to open a plant to make new product "akin to Konka."39 This was potentially an infringement of patent 34,845 . In 1927 Roland Moore Maunder with his assignee Frederick George Beaven of Wanganui took the Wanganui Sash and Door Factory and Timber Co. Ltd. to court. ${ }^{40}$ The Supreme Court ruled the patent was invalid, so in July 1928 Maunder and Beaven took the case to the Court of Appeal, ${ }^{41}$ which both allowed the appeal and for it to be appealed to the Privy Council. ${ }^{42}$

Before the case was heard in the Privy Council, Maunder, Beaven and Bassett and Co. Ltd. petitioned the Supreme Court to

\footnotetext{
${ }^{38}$ New Zealand Gazette (6 August 1925) n 58, pp 2376, 2380.

39 "Local and General" p 4.

40 "Concrete Tiles" p 10.

41 "Patent Appeal Case" (12 July 1928) p 4.

42 "Patent Appeal Case" (19 July 1928) p 13.
}

extend patent 34,845 for a further term, ${ }^{43}$ and the hearing was set for 4 April 1930.44 However, the judgement of the Privy Council was delivered on 24 January 1930, while noting Konka was the "trade name for their patented article" declared that as "the patentee took no inventive step" the patent was invalid. ${ }^{45}$ No extension of term occurred. This judgement opened the market for other similar products.

\section{NZ Standard Model Building By-law}

Following the 3 February 1931 Napier earthquake, the Government established a Building Regulations Committee to consider issues of earthquake resistant design and construction. They reported with a draft of a General Earthquake Building By-law and a recommendation for Uniform Building Code. ${ }^{46}$ The secretariat of the New Zealand Standards Institution had been established in August 1932,47 so it was commissioned by the Government to develop the New Zealand

${ }^{43}$ New Zealand Gazette (3 October 1929) n 66, p 2602.

${ }^{44}$ New Zealand Gazette (19 December 1929) n 85, p 3334.

${ }^{45}$ Russell. Wanganui Sash and Door Factory and Timber Company Limited v Maunder $\mathrm{p} 4$.

${ }^{46}$ BRC "H-21 Report of Building Regulations Committee" v II, pp 2-3.

${ }^{47}$ DSIR "Department of Scientific and Industrial Research (Seventh Annual Report)" p 6 
Standard Model Building By-law. This was completed by December 1935,48 given the number NZS 95 and divided into ten sections. In 1939 it was revised, becoming NZSS 95 and divided into parts (rather than sections).

The first version of the Model Building Code did not include light timber framing, so further work was required. The "Flats and Apartment House By-laws Committee" first met on 28 April 1938,49 with its work "NZSS 95 Part IX Light Timber Construction" published in February 1944. The Committee included representatives of the Municipal Association of NZ, NZ Institute of Architects, Fire Underwriters Association and the Health Department.

While on one hand the Committee was active in seeking information on current building practice, on the other hand manufacturers and suppliers were also keen to ensure their products could be used under the new model by-laws. As a result, the Committee files hold correspondence listing the use of a number of cladding boards, such as: "Excel Board" cement board, "Rotorua" board, which is

${ }^{48}$ Galbraith The New Zealand Standards Institute.

${ }^{49}$ NZSI "Minutes of the Inaugural Meeting of Flats and Apartment House By-laws Committee." similar to "Konka," "Thermax" board, "Duro" board, "Walasco" cement board, "Gibraltar" board, "Fibrolite" board. ${ }^{50}$

Excell Board (also spelt "Excel") was advertised by Bay Hardware Co of Tauranga as " $1 / 2$ in thick reinforced concrete board," which when new was "soft enough to saw and nail on" but "sets as hard as stone." It contained "no Plaster of Paris, and does not deteriorate like the softer sheets." 51 The description is very similar to Konka board.

Amongst those contacting the Committee was John Jackson \& Co Ltd of Timaru. They were keen to ensure that Konka would be acceptable under the new code and to this purpose providing a copy of their advertising

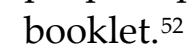

The committee undertook investigations into the suitability and durability of Konka board, including asking government agencies for their views. The Public Works Department Resident Engineer at Whanganui reported

${ }^{50}$ City Engineer, City of Auckland "N.Z. Standard Code of Building By-laws" p 1.

51 "To Builders and those about to build" p 4.

${ }^{52}$ John Jackson \& Co. Ltd "Letter to New Zealand

Standards Institute Concerning "KONKA" Board" $\mathrm{p} 1$. there were three manufacturers of a similar type of board in the city - Bassett and Co Ltd, the original manufacturers of "Konka," Messrs AW Brown, timber merchants, and the Wanganui Sash and Door Company. ${ }^{53}$ It is likely that one of the last two made the product called "Wangan board."

\section{Discussion \& Conclusion}

Konka board was not only New Zealand invented and manufactured, it was made from local materials (cement, pumice and flax tow). It competed with asbestos cement boards, although at the time the long-term human damage from asbestos was not well recognised. It is interesting to note that ultimately it was a Konka style approach which led to cellulose fibre replacing asbestos in the ubiquitous fibre-cement sheet. In the twenty-first century, Konka could even be considered a desirable product - a natural fibre reinforced, composite sheet.

Konka was widely used, with manufacturing plants in both the North and South Islands. Less than a year after the first advertisement, it had been approved for houses funded by State Advances, and just seven years later

${ }^{53}$ NZSI "'Konka" Board" pp 2-3. 
could claim $75 \%$ of home built in Wanganui were made of Konka.

The 1930s saw Konka board fitting into the new Model Building By-law, creating an opportunity for it to be used through New Zealand without additional engineering or other specialist reports. Even into the 1950s product demand was sufficient for it to be advertised in the 1952-52 first edition of Cranwells Building Supplies Catalogue.

By the 1960s Konka was no longer competitive. Flax production was in terminal decline. The Konka manufacturing process was labour and time intensive. Imported products were cost competitive. Yet the legacy of Konka remains with many hundreds of houses in different parts of New Zealand. 


\section{REFERENCES}

"A \& P Show" Manawatu Standard (4 November 1914): 5.

Aitkens Concrete Ltd "Aitkens Concrete Ltd - 100 Years in Concrete and the Gisborne Building Industry" Concrete (2009): 8-9.

Bay of Plenty Times, Bay of Plenty Times [Electronic Version Accessed through: Paperspast.natlib.govt.nz (1875-1920)] (Tauranga, N.Z.)

"Build Your Homes [Advertisement]" Timaru Herald (12 October 1931): 16.

Building Regulations Committee (BRC)"H-21 Report of Building Regulations Committee" Appendix to the Journals of the House of Representatives: 1931 Session I-II, 2 vols. Wellington, N.Z.: Government Printer, 1931.

https:/paperspast.natlib.govt.nz/parliamentary/AJHR1931-I-II.2.2.6.24

"Business Notes" Wanganui Herald (4 August 1918): 8.

Carroll, Brian A Very Good Business: One Hundred Years of James Hardie Industries Limited 1888-1988 Sydney N.S.W.: James Hardie Industries, 1987.

City Engineer, City of Auckland "N.Z. Standard Code of Building Bylaws, Part XI: Light Timber Construction" 9 October 1940, Archives New Zealand Wellington, AEKP 19011 ST6/25 95 Part 9.

"Commercial" Manawatu Standard (21 August 1915): 6.

"Concrete Tiles" Evening Post (21 September 1927): 10.

Cranwells Building Supplies Catalogue Auckland N.Z.: Cranwell Publishing Ltd.

Critchfield, Howard J. "Phormium Tenax: New Zealand's Native Hard Fiber" Economic Botany (1951) 5(2):172-184.

The Cyclopedia of New Zealand: Taranaki, Hawke's Bay and Wellington Provincial Districts Christchurch: The Cyclopedia Company Limited, 1908. VI.

DB Group PLC "UK Waterproofing Solutions, Waterproof Membranes,
Gas Proofing \& Concrete Waterproofing for Construction" DB Group (Holdings) Ltd, 2021. https://dbgholdings.com/pudlo/

Department of Scientific and Industrial Research (DSIR) "Department of Scientific and Industrial Research (Seventh Annual Report)" Appendix to the Journals of the House of Representatives (Wellington N.Z., 1933) Session I, H-34.

https://paperspast.natlib.govt.nz/parliamentary/AJHR1933-I.2.3.2.30

"'Eternit" [Advertisement]" Evening Post (10 September 1907): 7.

Exhibition of New Zealand Industries, King Edward's Barracks, Cashel St., Christchurch: Official Souvenir Catalogue Christchurch N.Z.: Industrial Corporation of New Zealand, 1922.

Galbraith, A.R., The New Zealand Standards Institute. Its Origin, Objects, and Organization Being a Report, Synopsis, and Technology Wellington N.Z.: Government Printer, March 1939.

"Harbour Board" Timaru Herald (23 July 1921): 9.

Hawera \& Normanby Star, Hawera E Normanby Star [Electronic Version Accessed through: Paperspast.natlib.govt.nz (1880-1924)] (Hawera, N.Z.)

Isaacs, Nigel P. "Making the New Zealand House 1792-1982" Wellington: unpublished PhD, Victoria University of Wellington, 2015. http://hdl.handle.net/10063/4804

John Jackson \& Co Ltd Cosy "Konka" Homes of New Zealand (Timaru, N.Z.: John Jackson \& Co. Ltd, 1923), Archives NZ Wellington, AEKP 19011 ST6/24 Record 95 Part 9

John Jackson \& Co. Ltd "Letter to New Zealand Standards Institute Concerning "KONKA" Board," 13 March 1940, Archives NZ Wellington, ADSQ 17639 F1/564 45/119/2 Part 5.

"Konka" Manawatu Standard (4 November 1914): 5.

"Konka Building System" Manawatu Times (30 June 1916): 6.

"Konka Defies Time Fire Rot Borer [Advertisement]" Timaru Herald (4 
March 1930): 14.

"Local and General" Hawera \& Normanby Star (16 July 1924): 4.

Maunder, Roland Moore "Reinforced Concrete Tiles" (Palmerston North, 1914) Patent case number: 34845

https://app.iponz.govt.nz/app/Extra/IP/PT/Qbe.aspx?sid=63773944686 3168392

Maunder, Roland Moore, "Wall, Fence, Etc Construction" (Palmerston North, 1916) Patent case number: 37354

https://app.iponz.govt.nz/app/Extra/IP/PT/Qbe.aspx?sid=63773944686 3168392

Maunder, William Steere, and Roland Moore Maunder "Improvements in Clothes Horses" Patent case number: 12221 (Ashurst, 1899)

https://app.iponz.govt.nz/app/Extra/IP/PT/Qbe.aspx?sid=63773944686 3168392

New Zealand Gazette [Electronic Version 1841 to 2008] (Wellington, N.Z.:

Department of Internal Affairs)

New Zealand Standards Institute (NZSI) "'Konka" Board - Summary of Letters \& Memorandum" 21 August 1940, Archives New Zealand Wellington, ADSQ 17639 F1/564 45/119/2 Part 5.

New Zealand Standards Institute (NZSI) "Minutes of the Inaugural Meeting of Flats and Apartment House By-laws Committee" (New Zealand Standards Institute, 1938), Archives NZ Wellington, ADSQ 17639 F1/563 Record 45/119/2 Part 1.

"Patent Appeal Case" Evening Post (12 July 1928): 4.

"Patent Appeal Case" Evening Post (19 July 1928): 13.

"Public Notice: Popular Furnishing Company" Wanganui Herald (6 August 1918): 7.

Russell, J, Wanganui Sash and Door Factory and Timber Company Limited v Maunder [1930] NZPC 1; [1930] UKPC 9; (1930) NZPCC 484 (24 January 1930), 1931.
http://www.nzlii.org/nz/cases/NZPC/1930/1.html

"Solving the Housing Problem" Wanganui Chronicle (31 May 1919): 3.

Sparrow, Christopher J. "The Growth and Status of the Phormium Tenax Industry of New Zealand" Economic Geography (1965) 41(4): 331-345. https://doi.org/10.2307/141944

Swarbrick, Nancy "Flax and Flax Working" Te Ara: The Encyclopaedia of New Zealand Wellington N.Z.: Manatū Taonga Ministry for Culture and Heritage, 2007. https://teara.govt.nz/en/flax-and-flax-working

"To Builders and those about to build [Advertisement]" Bay of Plenty Times (11 July 1947):4.

"Wanted - All architects [Advertisement]" Manawatu Standard (11 September 1914): 1.

Wrigglesworth, Karen, Take Me with You! : A Self-Drive Guide to Whanganui's Engineering Heritage Whanganui: Cliff Creatives, 2020. 